\title{
Inclusão e Exclusão Social em Programas de In- tervenção Urbana: o Programa Social e Ambien- tal dos Igarapés de Manaus - PROSAMIM
}

\author{
Ana Beatriz de Souza Esteves \\ Orientador: Michelangelo Giotto Santoro Trigueiro \\ Dissertação de Mestrado \\ Data da defesa: 23.03.2012
}

- ssa dissertação é resultado de um trabalho de pesquisa realizado com o objetivo de analisar as consequências sociais decorrentes da política de reassentamento à qual foram submetidas as famílias pertencentes às envoltórias de intervenção do Programa Social e Ambiental dos Igarapés de Manaus - PROSAMIM. Pretendeu-se, desse modo, compreender e explicar a relação entre determinada política urbana e seus impactos sociais, em um contexto histórico e espacial específico. O objetivo principal foi buscar um entendimento a respeito da relação entre inclusão/exclusão social nessa política urbana específica, utilizando, para isso, metodologias quantitativa e qualitativa de pesquisa, realizadas por meio das técnicas survey e entrevista semiestruturada, ambas aplicadas entre beneficiários da primeira edição do citado Programa.

Palavras-chave: Sociologia Urbana, Urbanização de Favelas, Igarapés de Manaus. 